\title{
IAMJ
}

INTERNATIONAL

AYURVEDIC

MEDICAL JOURNAL

Review Article

ISSN: 2320-5091

Impact Factor: 6.719

\section{CLINICAL APPLICATION OF DASHVIDHA PARIKSHA}

\author{
Lalit Tiwari $^{1}$, Shashi Kant Tiwari ${ }^{2}$ \\ ${ }^{1} \mathrm{PG}$ Scholar, ${ }^{2}$ Assistant Professor \\ Uttarakhand Ayurved University, Rishikul Campus, Haridwar, Uttarkhand, India
}

Corresponding Author: lalittiwari2009@gmail.com

\section{https://doi.org/10.46607/iamj1409062021}

(Published Online: June 2021)

Open Access

(C) International Ayurvedic Medical Journal, India 2021

Article Received:20/05/2021 - Peer Reviewed:09/06/2021 - Accepted for Publication:10/06/2021

Check for updates

\section{ABSTRACT}

Ayurveda is the science which describe various method to examine the Rogi (patient). These methods are patient friendly because these does not require any complicate procedure and not costly to patient. It is necessary to assess the Bala (Strength) of the patient before starting the treatment. The best way to assess the Bala of patient is Dashvidha Pariksha as described by Acharya Charak. If physician does not examine the patient properly, he can give wrong treatment to patient. With the help of Dashvidha Pariksha we can assess the Bala of both Roga (Disease) and Rogi (patient). VikritiPariksha (Examination of disease) is used to assess the Balaof Roga while other nine Pariksha are used to assess the Bala of Rogi (patient). On the basis of assessment of Dashvidha Pariksha physician can plan proper treatment for patient.

Keywords: Dashvidha Pariksha, Bala, Roga, Rogi.

\section{INTRODUCTION}

The primary aim of Ayurveda is to maintain the health of healthy person and to cure the disease is the second one. This unique objective of Ayurveda maintains the superiority among all the prevailing system of health care even if today. The importance of diagnosis of disease is underline by almost all the Ayurvedic
Acharya told, by Acharya Charak meaning that it is important to diagnose the disease first before starting treatment. If we don't consider the Roga and RogiBala and start the treatment it may leads to failure of the treatment. There are many methods described by various Acharya for the diagnosis of disease and to ac- 
cesses the Bala of the patients like Dwidhapariksha, Trividha Pariksha, Chaturvidha Pariksha, SadhavidhaPariksha, Asthavidha Pariksha, Dashavidha Pariksha, DwadashaPariksha.

Acharya Charaka has described the Dashavidha Parikshya Bhavato be examined in the patients which are- Kaarana, Karana, Karyayoni, Karya, Karyaphala, Anubhandha, Desh, Kala, Pravruti, Upaya. ${ }^{3}$ By the knowledge of these factors it is easy for the physician to treat the disease.

Here Desha is further subdivided into Bhumi Desha and Aatura Desha. Dashavidhapariksha comes under the Aatur Desha. In the Dashavidha Pariksha following ten points are examined to access the Roga and RogiBala.

$\begin{array}{lcr}\text { 1-Prakriti } & \text { 2-Vikriti } & \text { 3-Sara } \\ \text { 4-Samhanana } & \text { 5-Parmana 6-Satmaya } & \\ \text { 7-Satwa } & \text { 8-Aaharshakti } & \text { 9-Vyayamshakti }\end{array}$

10-Vaya ${ }^{4}$

\section{Aim and Objective}

The conceptual study of Dashvidha Pariksha on the basis of Ayurvedic Classics.

\section{Material and Methods}

This article is review article therefore Ayurvedic classics used in the study are Charak Samhita, Sushruta Samhita, Astang Hridya and their available commentary.

\section{Review of Dashvidha Pariksha}

1) Prakriti- The body of foetus is determined by the constitution of sperm and ovum, that of time and uterus that of food and behaviour of the mother and that of the products of Mahabhutas. Dosha one or more than one which predominates in these factors gets attached to the foetus. This is said as Dosha Prakriti of human being emerged from the initial stage of foetus. Hence some people are constitutionally Slesmala (Kaphaja), some Pittala, some Vatala some being combined Dosha and some with Balanced Dhatus. ${ }^{5}$

Acharya Shusruta says that whichever the Doshas that is predominant at time of union of Sukra (semen) and Sonita (ovum) the Prakriti of the person gets formed from the particular Doshas. In Sutra Sthan Achrayacharak says that as these Doshas are present at time of birth, therefore it is called Deha Prakriti. ${ }^{6}$ Acharya
Charak, Shusruta and Acharya Vagbhatta described seven type of Deha prakriti which are as follow

1) Vataja Prakriti

2) Pittala Prakriti

3) Kaphaj Prakriti

4) Vatapittala Prakriti

5) Pittalkaphaj Prakriti

6) Vatakaphaja Prakriti

7) Sama Prakriti

A) Slesmaja (Kaphaja) Prakriti- Slesma unctuous, soft, sweet, essence, solid, dull, rigid, heavy, cold, slimy and clear. Because of its unctuous the person with predominance of Kapha has unctuous organs, due to smoothness smooth organs, due to softness pleasing, delicate and fair organs, due to sweetness abundant semen, sexual act and progeny, due to nature of essence excellent, compact and stable body, due to solidity all organ well-developed and perfect, due to dullness dull in activities, diet and speech, due to rigidity delayed initiation, irritation and disorder, due to heaviness movements supported with essence and stability, due to coldness little hunger, thirst, pyrexia and perspiration, due to sliminess well united and strong joint ligaments, due to clarity eyes and face with clear and unctuous complexion and affectionate voice. Because of the presence of these qualities the Slesma person are strong, wealthy, learned, brave, clam and long lived. ${ }^{7}$

Person of Kapha Prakriti imitate Brahma, Rudra, Indraand Varuna, animals such as lion, horse, elephant, cow, bull, red eagle and swan ${ }^{8}$

B) Pitta Prakriti- Pitta is hot, sharp, liquid of fleshy smell, sour and pungent. Due to hotness the persons having predominance of Pitta are intolerant to heat, having hot face, delicate and fair organs, plenty of moles, freckles, black moles an and pimples excessive hunger and thirsty, early predominance of wrinkles, greying and falling of hairs, mostly soft, sparse and brown beard moustaches, small hairs, due to sharpness sharp prowess, intense fire, taking plenty of food and drinks, lack of endurance, frequent eating, due to liquidity lax and soft joints and muscles, excess excretion of sweat, urine and faeces, due to fleshy smell excessive foetid smell, in axilla, mouth, head and 
body, due to pungency and sourness little semen, sexual act and few progeny, because of presence of these qualities the person having predominance of Pitta are moderate in strength, life span, knowledge, understanding, wealth and means. ${ }^{9}$

Person of pitta Prakriti imitate in their activities, animals such as snake, owl, Gandharava, Yaksha, cat, monkey, tiger, bear and mongoose ${ }^{10}$

C) Vata Prakriti- Vata is rough, light, mobile, abundant, swift, cold, coarse and non-slimy. Due to roughness the person with predominance of Vata have rough, undeveloped and shot body, continuously rough, weak ,low , adhered and hoarse voice and vigils, due to lightness light and unsteady movements, activities, diet and speech, due to mobility unstable joint, eye brows, jaw , lips, tongue, head, shoulder, hands and feet, due to abundance of tendons and venous network, due to swiftness hasty initiation, quick irritation and disorder, quick in fear, attachment and disenchantment, quick in acquisition but with a poor memory, due to coldness intolerant to cold, continuously infliction with cold, shivering and stiffness, due to coarseness coarse hairs, beard moustaches, small hairs, nails, teeth, face, hands and feet, due to sliminess cracked body parts and constant sound in joints during movements. Because of presence of these qualities the person having predominance of Vata have mostly low degree of strength, life span, progeny, means and wealth. ${ }^{11}$

Person of Vata Prakriti are described as imitating goat, goyal ox, rabbit, rat, camel, dog, vulture, crow, donkey etc. ${ }^{12}$

2) Vikriti-Vikriti is Vikara (disorder). ${ }^{13}$ The disorder should be examined in the terms of the strength of cause, Doshas, Dushya, Prakriti, Desha, Kala, Bala, and also by Lingh, because of severity of disease cannot be known without knowing the strength of cause etc. The disease having similar to that of Dushya, Prakriti, Desha, Kala along with Bala and Lingh is severe is taken as Balwan Vyadhi. The contrary is Avara. The Madya Bala Vyadhi has similarity in one of the Dosha, Dushya etc and such as Madhya Bala of Hetu and Lingh.
3) Sara- There are eight type of Sara in human being which are described here for the knowledge of the Bala. The name of eight type of Sara are-

a) Tavak; b) Rakta; c) Mansa; d) Meda; e) Asthi; f) Majja; g) Sukra; h) Sattva

The Sara indicates the essence of Dhatu. Among all of the Sara, Sattva Sara is considered best of all. The person having character of all Sara are very strong and happy, enduring, confident in all actions, inclines to benevolent acts, having firm and balanced body with balanced movements, resonant, melodious, deep and high voice, endowed with happiness, supremacy, wealth, enjoyment and honour, with slow ageing and pathogenic process, mostly having similar and numerous offsprings and are long lived. ${ }^{14}$ Those having no Sara are contrary to these. Those having Madhya Sara should be known by their respective qualities in moderate degree.

Thus, eight type of Sara are described for knowledge of Bala in person.

4) Samhanana- Samhanana, Samhati and samyojanaare synonym ${ }^{15}$.

\section{Pravara Samhanana}

A well compact body is known by evenly demarcated bones, well bound joints, well-formed muscles and blood. Those having well compact body are strong

\section{Madhayama Samhana}

A moderately compact body is known by moderately demarcated bones, moderately bound joints, moderately formed muscles and blood.

\section{Avara Samhana}

A weakly compact body is known by weakly demarcated bones, weekly bound joints, weekly formed muscles and blood.

5) Pramana- Acharya charak and Shusruta had described different Angula Pramana of each Pratyanga (body parts).

Anguli Pramana: The pratyanga of hasta (hand) \&pada (feet) are stated as Anguli, each Hasta and Pa$d a$ has five Pratyanga in number. The name of Pratayang starting from thumb to little finger are-Angushta for thumb, Pradeshini for index finger, Madyama for middle finger, Anamika for ring finger and Kanishtika is for little finger. 
Ayam \& Vistara: The height of a person is called as Ayam\& Breadth (Arm span) it means distance taken from the tip of middle finger of Right hand to the tip of middle finger of Left hand is called as Vistara.

According to Acharya Charak the Ayamis 84 Anguli, Acharya Shusruta the Ayam is 120 Anguli, and According to Astang Hridaya Sharir the Ayamis 31/2 hasta.

If the Ayam of a person is approximately equal to breadth of that person, and size of Anga and Pratangya is according to which are described in Ayurvedic Classics, the person will have longevity of life with good strength of body.

6) Satmya-Satmya is that which being used constantly has wholesome effect, those suited to ghee, milk, oil and meat soup, and to all Rasas are strong, enduring and long lived. On the contrary, those suited to rough diet and single rasa are often weak, unenduring, short- lived and with a little means. Those having mixed suitability have medium strength. ${ }^{16}$ Acharya Shusruta says that Satmya is the use of such thing which do not cause the harm to the body even though they are opposite of different from one's own constitution, habitat, time, caste, season, disease, exercise , water, day sleep, tastes and such others. ${ }^{17}$

That taste which when consumed makes for happiness only, apart from that produced by exercises and others should be considered as Satmya.

7) Sattva-Sattva is the capacity of the mind which does not causes frustration at time of sorrow, joy etc. Acharya Shusruta has classified Sattva in Sattva guna, Rajguna and Tamoguna. ${ }^{18}$ The person who has Sattva guna tolerates everything remaining under control by himself, he who has Rajoguna tolerates when control by others, and he who has Tamoguna cannot tolerate at all. According to Acharya Charak Sattva is known as mind. He had divided Sattva in Pravara,Madhya and Avara Sattva. Accordingly, the persons are also having Pravara, Madhya and Avara Sattva Purusha. Amongst them those having Pravara Sattva are in fact SattvaSara and have been described in context of Saras.

They, though possessing, short body are seen unmoved even in severe afflictions- innate or exoge- nous- due to predominance of Sattva quality. Those having Madhya Sattva sustain themselves at the instance of others or entirely by others. But those possessing Avara Sattva can sustain neither by themselves nor by others, although having big stature, they are unable to endure even mild pain, they are associated with fear, grief, greed, confusion and conceit and even during fierce, frightening, disliked, disgusting and ugly narratives or on the look of the animal or human flesh or blood get afflicted with anxiety, abnormal complexion, fainting, insanity, giddiness or falling on the ground or even succumb to death. ${ }^{19}$

8) Aaharshakti-Aaharshakti is examined by the power of ingestion as well as digestion. Strength and life depend on diet. ${ }^{20}$

9)Vyayamshakti- The power of exercise should be examined by the capacity of work. The three types of strength are inferred from the capacity for work. ${ }^{21}$

10) Vaya-Vaya (Age) is defined as the state of body corresponding to the length of time. Vaya is broadly divided into three stage- Bala (Childhood), Madhya (Middle age), and Jirna (Old age). Childhood is determined up to sixteen years, when Dhatus are immature, sexual characters are not manifested, the body is delicate, unenduring, with incomplete strength and predominant in Kaphadosha. This again with Dhatus in developing stage and unstable mind remains up to thirty years. The middle age is characterized by strength, energy, virility, prowess, acquisition, retention, recollection, speech, understanding and qualities of all Dhatus having reached the normal limit, with proper physical and mental strength, without degeneration in qualities of Dhatus with predominance of Pitta Dosha and is upto sixty years. Thereafter is the old age upto one hundred years, During this period Dhatus, sense organs, strength, energy, virility, prowess, acquisition, retention, recollection, speech and understanding gradually degenerate, qualities of Dhatus go down and there is predominance of VataDosha. During this age, the measure of life span is one hundred years. There are people who live longer or shorter than that in such cases, one should determine the three division of age on the basis of strength 
of factors like Prakriti etc. and characters of different period of life span. ${ }^{22}$

Thus, one should determine the strength of the entities like Prakriti etc. except Vikriti in three divisionPravara, Madhya, Avara. According to severity of vikriti the three degrees of strength of Doshas are inferred. Then dividing the medicament also threedegree e.g. Tikshana, Mridu and Madhya. One should apply them according to Doshas.

\section{DISCUSSION}

Dashvidha Pariksha is a method of assessment of Bala in Rogi and Roga. Except Vikriti all other nine factor assess the Bala of Rogi while Vikriti is used to assess the Bala of Roga. If the physician assesses the Prakriti he can easily decide that which medicine is not suitable for particular Prakriti. Vikriti is used to assess the Bala of Roga. If all the factor of Vikriti is same the disease is difficult to treat. Sara assess the purity of Dhatus. If Sara is Pravar the Bala of Rogi will be good. Samhanana tells body built. Pramana is measurement of body and its parts. Satmya tells which things suit to patient and which do not. Sattva assess the mental strength of patient. Aahar Shakti is used to assess the digestive capacity. Vyayam is measurement of working capacity of person. Vaya tells about the age of patient, the Doshas predominance in that age.

\section{CONCLUSION}

Dashvidha Pariksha is one of the most important tools for examination of healthy as well as diseased person. With the help of DashvidhaPariksha the physician can assess not only physical health of patient but can also assess the mental health. On the basis of Bala of patient the medicament also three-degree e.g. Tikshana, Mridu and Madhya. Tikshana medicament should be given to PravarBala patient, Mridu medicament should be given to AvaraBala patient and Madhya medicament should be given to Madhya Bala patient. If medicament is given to without assessment of Bala of patient, it may produce ill effect or no effect to patient.

\section{REFERENCES}

1. SastriK., and Chaturvedi G., (2009), Charaka Samhita vidyotini Hindi vyakhayopeta Vol I Varanasi, Chaukhamba Bharati Academy pp.201

2. SastriK., and Chaturvedi G., (2009), Charaka Samhita vidyotini Hindi vyakhayopeta Vol I Varanasi, Chaukhamba Bharati Academy pp.406

3. SastriK., and Chaturvedi G., (2009), Charaka Samhita vidyotini Hindi vyakhayopeta Vol I Varanasi, Chaukhamba Bharati Academy pp.771

4. Sastri K., and Chaturvedi G., (2009), Charaka Samhita vidyotini Hindi vyakhayopeta Vol I Varanasi, Chaukhamba Bharati Academy pp.771

5. Sharma P.V. (2005), Charak Samhita, Vol I, $9^{\text {th }}$ edition, Varanasi, Chaukambha Orientalia, pp.375

6. Shastri A.D., (2012), Sushruta Samhita Vol I (ShariraSthan), Varanasi, Chaukhamba Sanskrit Sansthan, pp. 49

7. Sharma P.V. (2005), Charak Samhita, Vol I, $9^{\text {th }}$ edition, Varanasi, Chaukambha Orientalia, pp.376

8. Murthy K.R.S. (2004), Susruta Samhita, Vol I, $2^{\text {nd }}$ edition, Varanasi, (SariraSthan) Chaukambha Orientalia, pp.73

9. Sharma P.V. (2005), Charak Samhita, Vol I, $9^{\text {th }}$ edition, Varanasi, Chaukambha Orientalia, pp.377

10. Murthy K.R.S. (2004), Susruta Samhita, Vol I, $2^{\text {nd }}$ edition, Varanasi, (SariraSthan) Chaukambha Orientalia, pp.71

11. Sharma P.V. (2005), Charak Samhita, Vol I, $9^{\text {th }}$ edition, Varanasi, Chaukambha Orientalia, pp. 377

12. Murthy K.R.S. (2004), Susruta Samhita, Vol I, $2^{\text {nd }}$ edition, (Sarira Sthan) Varanasi, Chaukambha Orientalia, pp.71

13. Sharma P.V. (2005), Charak Samhita, Vol I, $9^{\text {th }}$ edition, Varanasi, Chaukambha Orientalia, pp.377

14. Sharma P.V. (2005), Charak Samhita, Vol I, $9^{\text {th }}$ edition, Varanasi, Chaukambha Orientalia, pp.379

15. Sharma P.V. (2005), Charak Samhita, Vol I, $9^{\text {th }}$ edition, Varanasi, Chaukambha Orientalia, pp. 380

16. 16.Sharma P.V. (2005), Charak Samhita, Vol I, $9^{\text {th }}$ edition, Varanasi, Chaukambha Orientalia, pp.381

17. Shastri A.D., (2012), Sushruta Samhita Vol I (Nidan Sthan), Varanasi, Chaukhamba Sanskrit Sansthan, pp. 175

18. Shastri A.D., (2012), Sushruta Samhita Vol I (Nidan Sthan), Varanasi, Chaukhamba Sanskrit Sansthan, pp. 175 
19. Sharma P.V. (2005), Charak Samhita, Vol I, $9^{\text {th }}$ edition, Varanasi, Chaukambha Orientalia, pp.382

20. Sharma P.V. (2005), Charak Samhita, Vol I, $9^{\text {th }}$ edition, Varanasi, Chaukambha Orientalia, pp.382

21. Sharma P.V. (2005), Charak Samhita, Vol I, $9^{\text {th }}$ edition, Varanasi, Chaukambha Orientalia, pp. 382

22. Sharma P.V. (2005), Charak Samhita, Vol I, $9^{\text {th }}$ edition, Varanasi, Chaukambha Orientalia, pp.383

\section{Source of Support: Nil}

\section{Conflict of Interest: None Declared}

How to cite this URL: Lalit Tiwari \& Shashi Kant Tiwari: Clinical Application Of Dashvidha Pariksha. International Ayurvedic Medical Journal \{online\} 2021 \{cited June, 2021\} Available from:

http://www.iamj.in/posts/images/upload/1237_1242.pdf 